\title{
THE MARKETING CHANNELS OF THE LOCAL FOOD PRODUCTION AND THEIR FOOD SAFETY REQUIREMENTS ${ }^{1}$
}

\author{
Nagyné Pércsi Kinga \\ associate professor \\ Faculty for Economics and Social Sciences, Szent István University \\ E-mail: nagyne.pecsi.kinga@gtk.szie.hu
}

\begin{abstract}
As the consequence of the modernization of the consumer habits and the intensive concentration process in retail sector there is an emerging need for building closer consumer- producer relations (Szabó, 2014).

Local food production and localized food supply chains, often referred as food relocalisation, have recently become the focus of attention among consumers, producers, as well as policy makers (Balázs, 2012). These systems have a long tradition in the United States and in Western Europe, and they also have deep historic roots in Hungary (Balázs et. al, 2015). In Hungary about $70 \%$ trust more in farmers, compared to $30 \%$ in stores (Eurobarometer, 2011).

The organic food producing activity is a special category in the range of local food production. The consumers usually keep the local food products healthier, fresher and safer as compared to the food marketed in the conventional food supply chains. This is even true for the organic food. In this case the consumers approve and appreciate the producing method also. However the market of organic products is quite small in Hungary, based on its development potential it has strategic importance (Szakály, 2004, in Szente, 2015).

Relating to the abovementioned the aim of this article is to introduce the main marketing channels of Hungarian local food production, the relating most important food safety problems. I paid a special attention to the marketing channels of local organic production, because in this product circle the food safety requirements have vital importance.
\end{abstract}

Keyword: food-safety, organic food consumption, consumers' attitude, purchasing behaviour, organic marketing channels

JEL Classification: $Q 19, R 10$

LCC: $S 1$

\section{Introduction}

The increasing market share of the corporate retail chains and the global food traders was very obtrusive at the beginning of the new Millennium and rather after the EU joining on the Hungarian food market. The increasing impact of large corporate retail chains in the Hungarian food market has had major repercussions on the purchasing patterns of consumers, as well as the distribution stream of Hungarian products (Csáki and Jámbor, 2009). In a short period not only was the landscape of the food retail scene completely changed, but also the consumption patterns of Hungarian citizens. This usurping of control of the food market in Hungary, and its

\footnotetext{
${ }^{1}$ This work was created in commission of the National University of Public Service under the priority project KÖFOP-2.1.2-VEKOP-15-2016-00001 titled "Public Service Development Establishing Good Governance" and the Cooperative Partner/Institution
} 
corresponding influence on consumer shopping patterns had repercussions on both the conventional and organic production sectors in Hungary (Balázs et al., 2015)

Relating to the above mentioned it should be noted that just as the consequence of the modernization of the consumer habits and the intensive concentration process there is an emerging need for building closer consumer- producer relations (Szabó, 2014). Local food production and localized food supply chains, often referred as food relocalisation, have recently become the focus of attention among consumers, various NGOs, producers, as well as policy makers (Balázs 2012, Benedek - Balázs 2014). Nagy et al (2017) stated that small local clusters with non-traded activities (such culinary products) can connect local suppliers and producers and these clusters can have impact on their surrounding region. These systems have a long tradition in the United States and in Western Europe, and they also have deep historic roots in Hungary, even if the tradition was dented by the rapid shift to factory farming first in the country's socialist era and then during the large scale commercialization of the food chain by multinationals after 1989 (Balázs et al., 2015).

The term Short Food Supply Chain (SFSC) covers a wide range of distribution channels and is considered to be more appropriate when it comes to empirical research. In SFSCs small geographical, social and cultural distance between producers is typical; such as the demand for environmentally friendly/conscious production and consumption patterns (Balázs et al., 2015).

Food relocalisation tendency is influenced by among other an increasing interest and a conscious claim for healthy, verifiable food products and for transparent supply chains. Products of small-scale producers are generally considered to taste better, be more nutritious and fresh, healthier, more reliable, and authentic, often despite not having any quality (eco, organic) or regional labels (Kneafsey et al. 2013). A Eurobarometer publication from 2011 recorded high support of local products in all EU countries: pointing out that half of EU citizens 'totally agree' that there are benefits to buying local food (Eurobarometer, 2011). According to another Eurobarometer survey the transparency of the supply chain and the problem of uncertain origin emerged as new factors in consumers' decision making processes in 2010. The uncertain origin emerged among 7\% of the surveyed citizens as a possible risk (Eurobarometer, 2010) Eurobarometer data also show that citizens are interested in food security issues, and an especially high portion of them in chemical content. Europeans indicate higher trust in farmers than the food supply in major supermarkets. In Hungary about $70 \%$ trust more in farmers, compared to $30 \%$ in stores. Europeans also prioritize the origin of food, and about $75 \%$ regularly check product labels (Eurobarometer, 2011).

The direct Short Supply Chains can be grouped in four main category. These are the followings "through intermediary", "with home delivery", "from open farm" or "on selling point". Every category has two subtypes, namely the traditional and the modern forms (Szabó, 2014). Hungarian modern direct distribution channels include ad hoc distribution events - focusing on seasonally available and limited varieties of products; various arrangements of box schemes/shopping communities (with usually 20-30 farmers and probably few hundreds of regular customers); websites providing access to local products and producers; web shops of local/farmers products (termelotol.hu; naturhalo.hu; kamratura.hu; 30km.hu; egyhazaji.hu) (Balázs et al, 2015).

The survey data of Csíkné Mácsai (2013) from 2011 showed that 84\% of the citizens buy food from the producer directly at least few occasions per year. The most popular direct selling form were the markets grouped to the traditional marketing point category. It has a share of $71 \%$. Juhász and Szabó (2013) analysed the market assessment of the producers and the consumers 
in their study and got the similar results. Most of the survey participants, $30 \%$, visit one of the Hungarian markets on weekly basis, while $14 \%$ use this marketing channel more than once a week.

In contrary with the abovementioned a nationally representative survey looked at food consumption patterns in Hungarian society and the public perception of supermarkets vs local food (Medián, 2012). The survey was carried out through 1200 personal interviews in July 2012 on a population over the age of 18 years old. The main lesson that can be learnt on food store choice is that Hungarians most often buy food either in local small food shops or in supermarkets - both retail venues are frequented by seven out of ten people. Only a minority of 13 percent directly buys food from farmers on a regular basis.

Local food shops or direct sales from farmers are more frequent in the rural areas and villages. In Budapest people typically prefer supermarkets, hypermarkets and at the same time farmers markets (Medián, 2012).

The consumers expect the products to be fresher, pure, healthy, natural, nutritious, better tasting and safe than their mainstream "industrial" counterparts. However it is questionable whether all of these expectations are realistic (Ter Kuile, 2012). However the consumers feel the local food bought in SFSC safer it should be mentioned that the small scale producers have gap in food hygiene knowledge. Additionally the authority put more emphasises on the control of high risk food producers, so the food safety conformity controls among small scale producers, whose product get to fewer consumers, has low rate. According to the data of NÉBIH (National Food - Safety Authority) only $2.8 \%$ of the total controlled food connected to the food producing, marketing and catering activity of small scale producers. In $2.2 \%$ of the controlled products punishment was inflicted, which was $1 \%$ higher than a year before in 2010 . According to the data from 31 July 2013 this ratio increased further with $2.7 \%$. The ratio of the withdrawn products was $0.5 \%$ in 2011, 1.7\% in 2012 while it reached 6\% in 2013 (Szabó, 2014). Jancsó (2015) compared the directly marketed raw milk and the processed milk hygienic characteristics and found that the aerobic mesophilic microorganism content well exceeded the remained under the limit $(100.000 \mathrm{cfu} / \mathrm{ml})$. It referred to serious hygienic problems that $46 \%$ of the analysed samples exceed $1.000 .000 \mathrm{cfu} / \mathrm{ml}$. Most of the results belonged to this category.

The organic food producing activity is a special category in the range of local food production. The consumers usually keep the local food products healthier, fresher and safer as compared to the food marketed in the conventional food supply chains. This is even truer for the organic food. In this case the consumers approve and appreciate the producing method also. Consumer interest in organic foods in Hungary is driven by the perceived health benefits associated with consuming goods free of chemical additives and pesticide residue (Balázs et al. 2015). On the other hand, solidarity with local producers, and the associated environmental benefits also drive sales. The consumers' trust, the personal and direct consumer - producer connection is dominant factor at purchasing decisions of organics. The organic food consumers are interested in who has produced food items they consume and where they have originated. Organic food consumers may also be motivated by knowing and supporting the individual who has produced their food as opposed to supporting a faceless corporation or distant producer (Strenchock, 2012).

Beyond the abovementioned health and environment protection, the food safety aspects, the sensory and the so called ethical quality characteristics mentioned by many studies as a motivation factor to buy organics (Tregear et al., 1994 in Ozguven, 2012; Magnusson et al., 2003 in Ozguven, 2012, Bilal et al, 2015). The organic food buyers have an inclination to pay 
higher price for the higher food safety requirements (Schifferstein - Oude Ophuis, 1998 in Ozguven, 2012). Most part of the organic food procurements are due to the environmental protection a food - safety aspects. It should be parallel mention that according to Csíkné (2014) the most important influencing factors at food procurement in the case of an average Hungarian consumer are the price, freshness, food - safety, and the choice. She found that the least important influencing factors are the direct personal contact with the farmers, the producing methods and decreasing of the environment pollution.

If we analyse the role of the direct selling in certain product circles it can be stated that the consumers buy fruits and vegetables, eggs, honey and milk from the producers. These products are purchased from the producers directly by $30 \%$ of the consumers (Csíkné Mácsai, 2014).It is also true for the organic food according to our survey but in a higher rate.

\section{Methodology}

On the basis of the literature review I introduced the main marketing channels of Hungarian local food production, the relating most important food safety requirements. I would like to pay a special attention to the local organic production and its marketing channels, because in this product circle the food safety requirements have vital importance. On the basis of a survey (Szente, 2015) referred more times in this article, the majority $(59,8 \%)$ of the respondent is neutral towards the organic origin of products. At the same time, in the case of local products, origin is partially or wholly important for as much as $72.9 \%$ of the interviewees. It is worth noting that $62.9 \%$ of those who prefer ecologically farmed food products also consider local origin important (Szente, 2015).

To underpin the characteristics of the Hungarian organic food marketing channels we made a survey on the biggest Hungarian Organic Food Market, on the organic market organized by the Biokultúra Alliance which is an interest protecting organization for the farmers. This market was controlled and certified by the largest Hungarian certification body, the Biokontroll Hungária Ltd. The questionnaires were filled up personally on February 2018. Altogether 31 persons could be interviewed this time. The surveyed persons had the opportunity to add their personal opinion to every single question, so this way we could note them and use them in data processing. The applied questionnaires contained 16 mostly closed questions which connected to the consumption pattern, diet, consumers' behaviour, attitude, purchasing channels and the demographic characteristics of the surveyed persons. As I mentioned the surveyed had the opportunity to add their personal opinion and ideas freely. Beside the abovementioned 842 questionnaires were collected with the help of the students attending to the courses of the Szent István University calling "Hygiene in catering" and "Quality assurance and food safety" until the given deadline. The task of the students was to interview their family and relatives, for example their grandparents or parents, aunts and uncles, cousins. It was a requirement that the respondent should be over 18. Among these 842 questionnaires only 102 was suitable for further processing, because only these 102 consumers buy food on organic markets regularly. I used these survey data in my analysis also. The number of the organic food consumers is more than 102 of course but they usually buy organic food in special store and retail chains.

\section{Results}

On the basis of our survey it can be stated that those who buy food on organic market are mainly women, in $67 \%$. Maybe it is not surprising that according to a representative survey from 2014 the women answered above the average that they are responsible for the food purchase in their family. The same study found that the women give higher attention to the health impact of food 
(Jakopánecz, 2015). 58\% of the respondents live in Budapest which can be caused by the high proportion of those who were surveyed in the Organic Market of Biokultúra in Budapest.

$61 \%$ of the respondent completed tertiary education as it was expected on the basis of the former surveys. $87 \%$ said that their income level per capita is on average or higher than average in their family.

According to a representative survey conducted by Medián in 2012 the healthy, seasonal and chemical free products are preferred by the population with higher qualifications and income (Medián, 2013). On the basis of another representative survey in 2014 (Szente, 2015) those, who buy organic products are predominantly women $(36.0 \%)$, tertiary education graduates $(39.9 \%)$, white-collar workers $(41.9 \%)$, or have average or above average income $(45.7 \%$ and $30.8 \%)$.

One of the interesting findings of our survey was the opinion of the organic market consumers about their knowledge in food-safety topics (Figure 1). They had to give a score for their own knowledge from 1-10. The average competence was 7.1, which means a high preparedness of the respondent in this field.

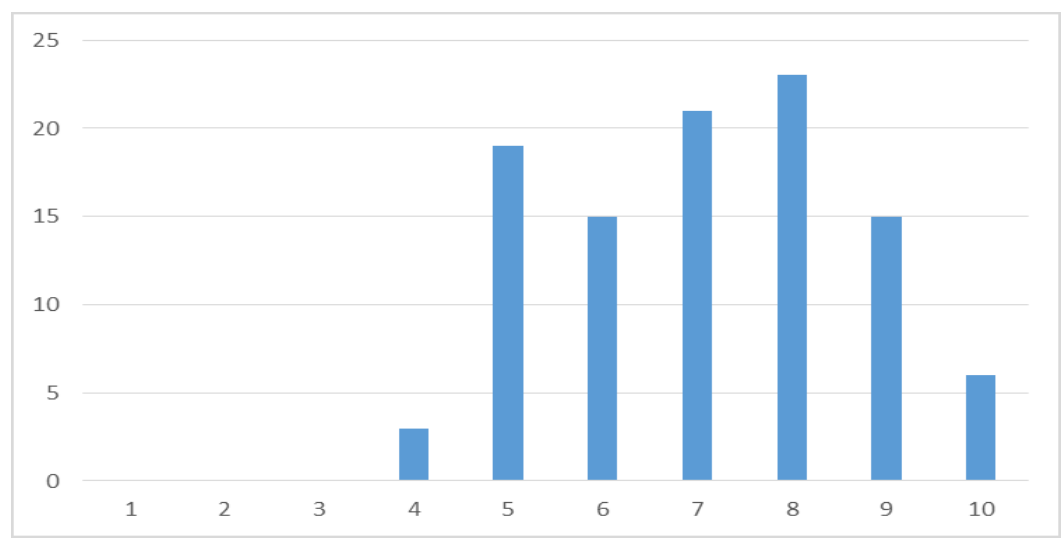

Figure 1: The distribution of the scores given by the organic market consumers for their food safety knowledge

Source: Own data collection and processing, 2018

Most of the respondent gave 8 or 7 scores for their own food-safety knowledge and nobody gave less than 4 .

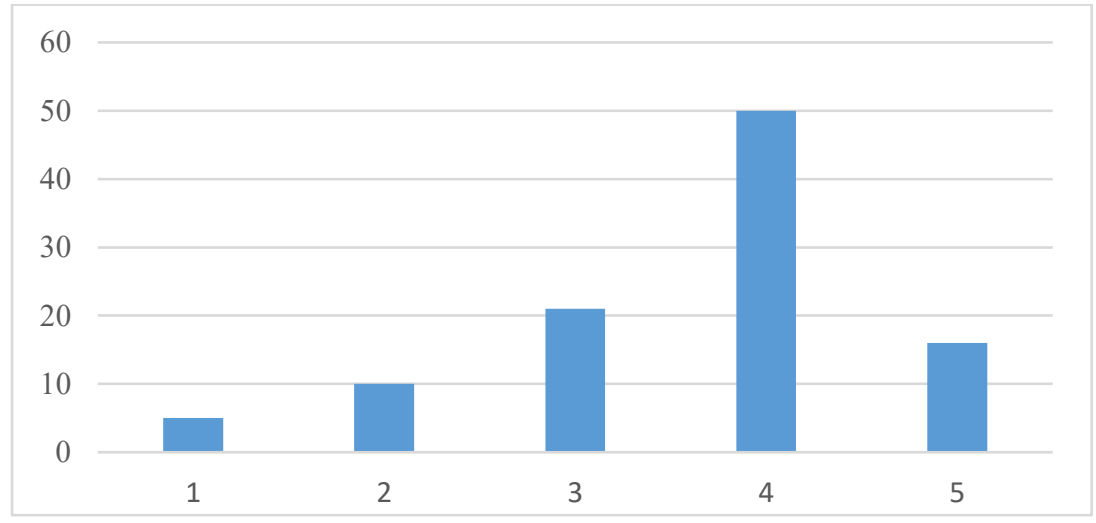

Figure 2: The effectiveness of the food - safety authority according to the respondent Source: Own data collection and processing, 2018 
On average the respondent evaluated the performance of the food - safety authority and the food - safety situation for 3.61 points. It means that the consumers think that the food -safety situation improved in some extent in the last few years. They had to give scores for the performance of the authority from 1 to 5 , in accordance with the Hungarian school grading system. Most of the respondent gave 4 (Figure 2).

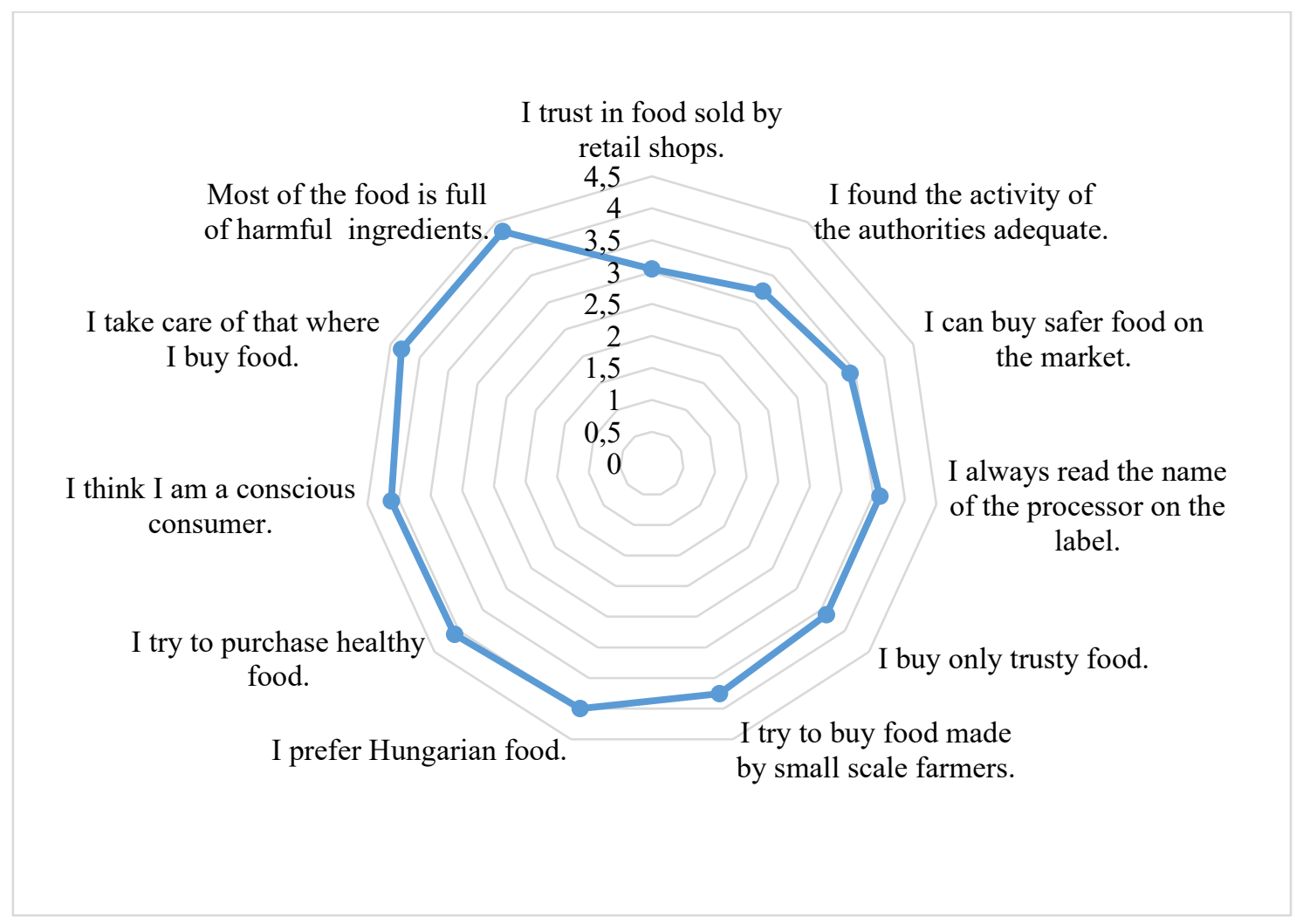

Figure 3: The attitude of the organic market consumers

Source: Own data collection and processing on the basis of Jakopánecz (2015), 2018

It is important and interesting results from the aspect of this analysis that the organic market consumers pay much attention to where they buy food. The respondents agreed in that in great extent. They mentioned on the sixth place that they try to buy food from small scale farmers. They do not think that they get safer food on the market and they do not trust in food traded by food stores (Figure 3).

According to our survey the most dangerous component in foods are the chemicals (Figure 4). This was underpinned by other relevant survey and in accordance with the most important purchase influencing factors (Bilal et al, 2015, Ozguven et al, 2012). It is interesting that the most important factors are corresponding with food safety requirements of the organics. They are free of chemicals, additives and GMO. The consumers percept mould contamination with the same risk rate as the GMO content, however the mould contamination can be a frequent risk in organic production. 


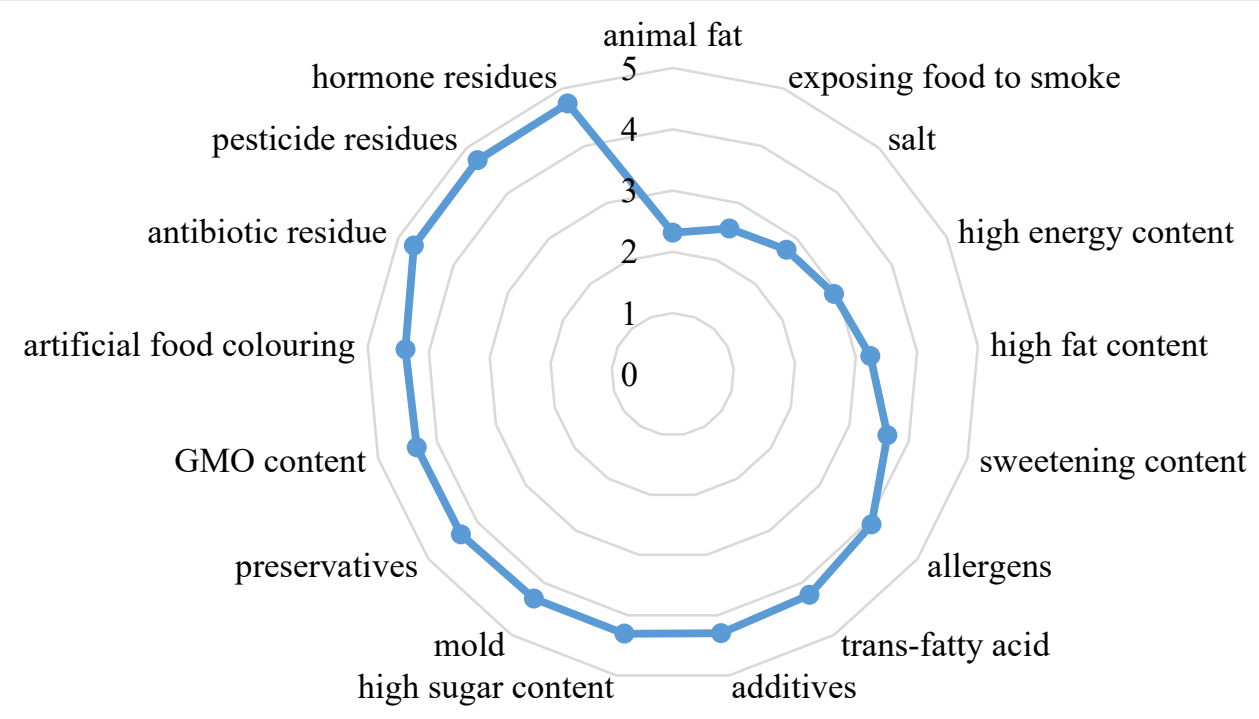

Figure 4: The most dangerous food contents according to the organic market consumers Source: Own data collection and processing, 2018

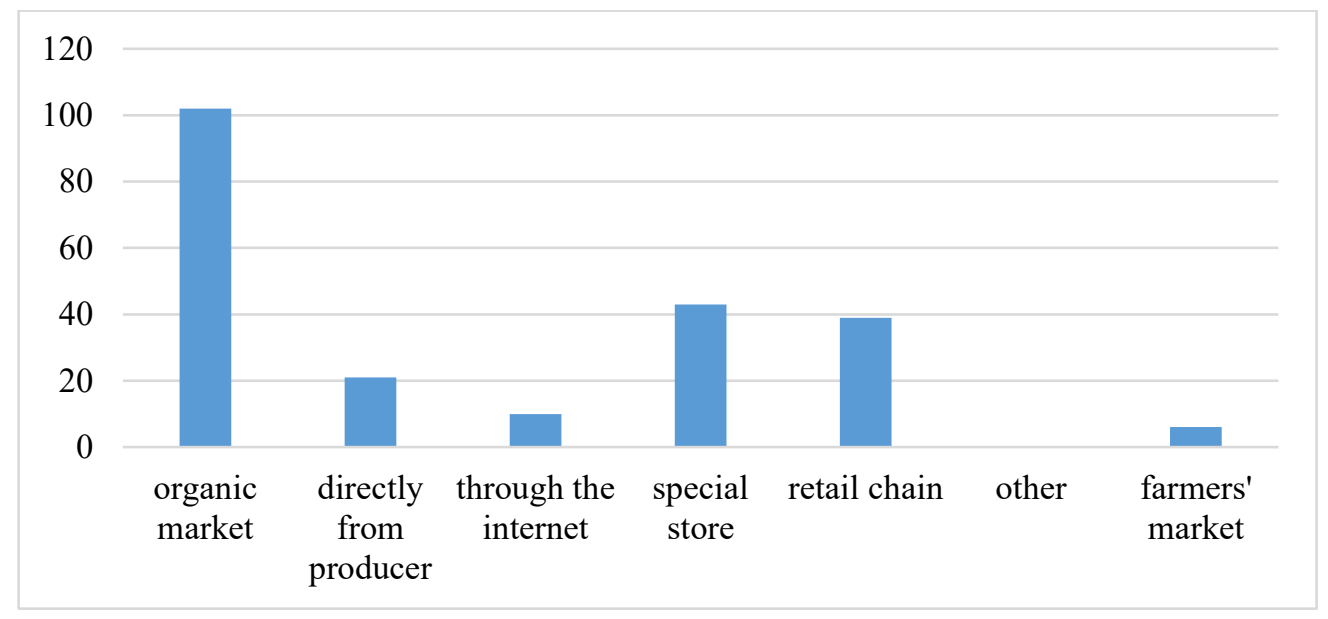

Figure 5: Marketing channels of the organic food

\section{Source: Own data collection and processing, 2018}

The most popular purchasing channel of the organic food was the organic market, which usually means a direct contact with the producers (Figure 5). Those consumers who were surveyed directly on the Organic Market in Budapest said solidly that they had direct relations with the farmers on the market. The second most popular form was the special store and the retail chains. Our findings are in accordance with Szente and Torma (2015).

Szente and Torma (2015) made a representative survey among the Hungarian consumers in 2013. They analysed the usual marketing channels of organic food. They found that the largest portion of respondents usually buy these products directly from the producers, it can be the consequence of that organic foods have a sort of "trust product" character. After the producers, the various specialist shops follow, which were also shown to be popular in earlier studies (Hamm et al., 2002; Schaak, 2013, Zagata, 2012). The different super and hypermarkets and smaller outlets were almost equally popular, which refers to the increasing accessibility of organic products. In the recent years, organic foods began to appear on the shelves of different discount stores in Hungary, $14.9 \%$ of the respondents maintained that they buy products from 
these outlets with some frequency. Purchasing from web stores is the least favoured option (Szente and Torma, 2015).

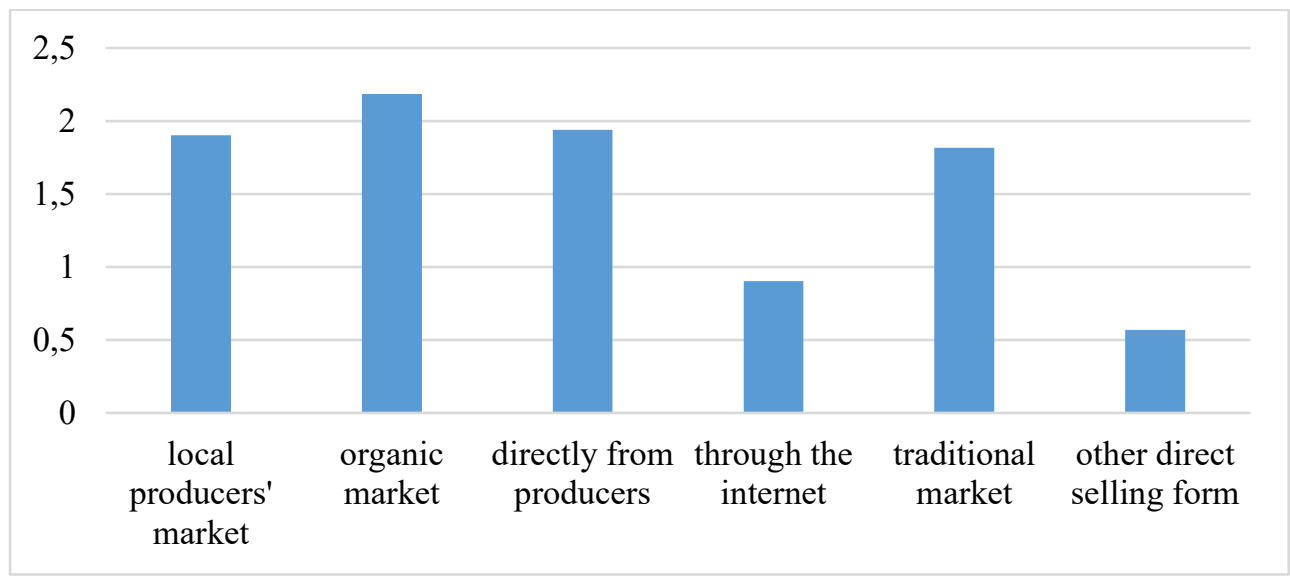

Figure 6: Purchasing frequency of the organic market consumers in different channels

Source: Own data collection and processing, 2018

The organic market consumers buy food with the highest frequency on organic market which is followed by the direct purchase from the producers and the local producers' market (Figure 6). The standard deviation was the lowest in the case of organic market, while it was the highest in the case of local farmers'/producers' market. According to the "on the spot survey" in Organic Market in Budapest the consumers (32) bought organic food on organic market on weekly basis. It is the consequence of that this market is organised once a week on every Saturday.

\section{Consequences}

However the consumers feel the local food bought in SFSC safer it should be mentioned that the small scale producers have gap in food hygiene knowledge. Additionally the authority put more emphasises on the control of high risk food producers, so the food safety conformity controls among small scale producers, whose product get to fewer consumers, has low rate (Szabó, 2014).

The organic food producing activity is a special category in the range of local food production. The consumers usually keep the local food products healthier, fresher and safer as compared to the food marketed in the conventional food supply chains. This is even truer for the organic food.

Consumer interest in organic foods in Hungary is driven by the perceived health benefits associated with consuming goods free of chemical additives and pesticide residue (Balázs et al. 2015). On the other hand, solidarity with local producers, and the associated environmental benefits also drive sales.

The surveyed organic market consumers feel themselves well prepared in food-safety questions. And they think the food safety situation improved somewhat in last few years.

Organic market consumers pay much attention to where they buy food. The respondent of the survey try to buy food from small scale farmers. They do not really think that they get safer food on the market and they do not trust in food traded by food stores. 
According to the respondent the most dangerous component in foods are the chemicals. This was underpinned by other relevant survey and in accordance with the most important purchase influencing factors (Bilal et al, 2015, Ozguven et al, 2012).

The most popular purchasing channel of the organic food was the organic market, which usually means a direct contact with the producers. The second most popular form was the special store and the retail chains. So the retail chain like Tesco, Auchan, Spar, etc. can be a marketing opportunity for organics in the future.

On the basis of our survey the organic market consumers buy food with the highest frequency on organic market which is followed by the direct purchase from the producers. This is in accordance with other authors' findings and also through for local food products (Mácsai, 2014). So the use of modern direct selling forms still lag behind the traditional ones. Many of the interviewees took part in the survey on the Biokultúra Organic Market have never heard about the "box system".

\section{References}

1. Balázs, B., Bertényi, G.,Králl, A., Pintér, L., Strenchock, L. (2015):PATHWAYS project Exploringtransitionpathwaystosustainable, lowcarbonsocieties, January 2015.

2. Bilal Bashaa, M., Masonb, C., Farid Shamsudinc, M.. Iqbal H., Milad Abdelnabi Salem, H. (2015): Consumers Attitude Towards Organic Food, International Accounting And Business Conference 2015, IABC 2015, Procedia Economics and Finance 31 ( 2015 ) $444-452$.

3. Euromonitor International (April 2011): "Health and Wellness: Market Sizes."

4. Euromonitor International (2011): "Consumer Lifestyles in Hungary." Euromonitor International, July 2011.

5. Euromonitor International (2010): Retailing in Hungary. Euromonitor International, May 2010.

6. Csáki, C., and Jámbor, A. 2009. The Diversity of Effects of EU Membership on Agriculture in New Member States. FAO Policy Studies on Rural Transition No. 20094

7. Csíkné Mácsai, É. (2014): Közvetlen értékesítés a mezőgazdasági termékek piacán. PhD Értekezés, Gödöllő, 2014.

8. InternationalMarketsBureau Canada (2013): The Hungarian ConsumerBehaviour, Attitudes andPerceptions TowardFood Products, Market Analysis Report, January 2013

9. Jakopánecz, E. (2015): Élelmiszer-vásárlási tudatosságés fogyasztói ellenállásra való hajlandósága magyar felnőtt lakosság körében. Dr. Törőcsik Marketing InspirációFogyasztói Magatartás Kutató Intézet, WHO Egészség Világnap, Élelmiszerbiztonság konferencia, 2017. április 7.

10. Juhász, A., Szabó, D. (2013): A piacok jellemzői fogyasztói és termelői szemmel, Agrárgazdasági Könyvek, AKI, Budapest, 142.o

11. Kneafsey, M.,Venn, L., Schmutz, U., Balázs, B., Trenchard, L., Eyden Wood, T., Bos, E., Sutton, G., Blackett, M. (2013): Short Food Supply Chains and Local Food Systems in the EU. A State of Play of their Socio-Economic Characteristics. JRC, 2013

12. Magnusson, M.K., Arvola, A., Hursti, U.K.K., Aberg, L., Sjoden, P.O. (2003) Choice of organic food is related to perceived consequences for human health and to environmentally friendly behaviour, Appetite 40(2), 109117

13. Medián (2013) Attitudes towards the social effects of food purchasing. Report for ESSRG. Manuscript in Hungarian in Kneafsey et. al., 2013 
14. Nagy, H., Illés, B., Káposzta, J., Donnik, I. (2017): Clusters and concentration of businesses in regions of some european countries as tools for economic development. ENGINEERING FOR RURAL DEVELOPMENT. (16.) 2017. ISSN 1691-3043 pp. 248-253. DOI: 10.22616/ERDev2017.16.N048

15. Ozguven, N. (2012): Organic foods motivations factors for consumers.Procedia Social and Behavioral Sciences 62 ( 2012 ) $661-665$.

16. Schifferstein, H.N.J., Oude Ophuis, P.A.M. (1998) Health-related determinants of organic food consumption in the Netherlands. Food Quality and Preference,9,3,119133

17. Strenchock, L. (2012) Local Food Systems in Budapest: Citizen Driven Conscious Food Consumption Initiatives to and their Ability to Shape New Food Paradigms in Hungary. Master's Thesis: www.etd.ceu.hu/2012/strenchock_logan.pdf

18. Szabó D. (2014): A rövid ellátási láncban rejlő lehetőségek és veszélyekMagyarországon. Acta Carolus Robertus, 4. (2), 109-118. p. http://epa.oszk.hu/02400/02498/00008/pdf/EPA02498_acta_carolus_robertus2014_2 109-118.pdf

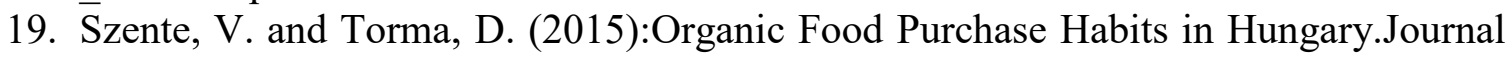
of Economic Development, Environment and People Volume 4, Issue 1, 2015.

20. Ter Kuile, B. (2012): Food safety problems specific to the short chain selected case studies from the Netherlands. Food Safety of Short Food Supply Chain, Symposium SciCom 2012

21. Tregear, A, Dent, JB, Mcgregor, MJ. (1994) The demand for organically grown produce. British Food Journal 94(4): 21 